\title{
NON-PERFORMING LOANS RESOLUTION AS ESSENTIAL FACTOR OF BANKING SECTOR STABILITY
}

\section{Vladimir Mirković}

Sberbank a.d, Beograd, Srbija

\section{Marija Knežević}

Procreditbank a.d, Beograd, Srbija

\section{(C) MESTE NGO}

JEL category: H12, H57, L82

\section{Apstrakt}

Poreklo krize u finansijskom sektoru potiče iz perioda kreditne ekspanzije tj. perioda kreditnog buma u zemljama u razvoju i tranzicionim ekonomijama. Naime, tokom perioda kreditne ekspanzije nije se dovoljno pažnje pridavalo rizičnosti kredita i kao posledicu imamo značajan rast ukupnih nenaplativih kredita (tzv. NPL kredita). Opisani procesi su, takođe, karakteristični i za srpsku privredu i bankarski sektor. Bankarski sektor Srbije je prošao kroz znatne strukturne promene u poslednjoj deceniji. lako su mnogo poboljšanja učinjena u poslovanju banaka i regulativi i dalje postoje nerešeni problemi praćeni nenaplativim potraživanjima, neizvesnošću na globalnim finansijskim tržištima $i$ visokom izloženošću operativnom riziku. Porast nenaplativih kredita treba posmatrati zajedno sa negativnim makroekonomskim pokazateljima, primarno sa: padom BDP-a i porastom stope nezaposlenosti, kao i likvidnosnim problemima banaka $i$ neadekvatnom strukturom prethodno odobrenih kredita. Preduzimanje mera za rešavanje pitanja NPL kredita i na taj način „čišćenja“ bilansa stanja banaka od dodatnog tereta, kojeg banke imaju u smislu vrlo značajnog učešća NPL kredita ostaju najveći izazov. Sa druge strane, kategorija nenaplativih kredita na najbolji način ukazuje na povezanost realnog $i$ finansijskog sektora i može se posmatrati kao paradigma opšteg pogleda na srpsku privredu. Efektivno $i$ efikasno funkcionisanje bankarskog sistema pretpostavlja identifikaciju $i$ razrešavanje pitanja nenaplativih kredita na način koji će obezbediti i održati stabilnost privrede u celini. Pitanja vezana za NPL kredite i njihovo rešavanje sa posebnim osvrtom na srpsku privredu su od esencijalnog značaja iz perspektive budućeg razvoja bankarskog sektora i kao takva zauzimaju glavno mesto u ovom radu.

Adresa autora zaduženog za korespodenciju: Vladimir Mirković 帮”- vladamirkovic@orion.rs
Ključne reči: nenaplativi krediti, banke, finansijski sistem, stabilnost, makroekonomska sfera, kriza, realni sektor, Srbija. 


\section{Abstract}

The origin of crisis in financial sector was created in a period of credit expansion i.e. period of credit boom in emerging and transition economies. Namely, during credit expansion there had not been sufficient caution regarding loan riskiness and as a consequence there was a significant growth of total non-performing loans (i.e. NPL loans). Described processes were inherent for Serbian economy as well banking industry. Banking sector in Serbia passed through significant structural changes in the last decade. Although there are many improvements in banking operations and their regulations, there are also unsolved problems accompanied with non-performing loans, uncertainty on global financial markets and high exposure to operational risks. Increase of NPL loans should be considered together with negative macroeconomic indicators primarily: GDP decrease and unemployment rate growth, as well as liquidity problems of banks and inadequate structure of previously disbursed loans. Taking adequate measures for NPL resolution and in that way "cleaning" bank's balance sheets from additional ballast, which they have in terms of more than significant share of NPLs, remains the biggest challenge. On the other hand, category of NPLs represents the best connection between real and financial sector and it could be observed as paradigm for Serbian economy overview. Effective and efficient functioning of banking system assumes identification and resolution of NPLs in the manner to provide and maintain the stability of economy as a whole. Issues regarding NPLs and its resolution with the focus on Serbian economy are essential from the perspective of future development of banking industry and that is the main subject of this paper.

Keywords: non-performing loans, banks, financial system, stability, macroeconomic sphere, crisis, real sector, Serbia.

\section{UVOD}

Globalna ekonomska kriza je pokrenula mnoga pitanja direktno vezana za regulativne i supervizorske aktivnosti u cilju obezbeđivanja stabilnosti finansijskog sistema. Istovremeno je akcenat na povezanosti mikro i makro prudencijalne supervizije, pa se u tom smislu mikro prudencijalna supervizija fokusira na praćenje finansijske situacije samih banaka u cilju zaštite klijenata od mogućeg širenja „zaraze“ u slučaju nastupanja krize kod pojedinačne banke. Makro prudencijalna supervizija je znatno šira, odnosi se na nivo nacionalne ekonomije, i orjentisana je na ukupni sistematski rizik, šokove koji mogu potencijalno izazvati „efekat prelivanja“ (tzv. „spillover effect”) kao i praćenje strukturnih i cikličnih trendova na finansijskim tržištima.

Kreditna ekspanzija u zemljama Centralne i Jugoistočne Evrope je poslednjih godina, a naročito u godinama krize, manifestovana kroz značajan porast nenaplativih potraživanja (u daljem tekstu: NPL kredita - NPL je akronim od engleskog izraza „non-performing loans“, što se u slobodnom prevodu može interpretirati kao: nenaplativa potraživanja). Različiti pristupi kvantifikovanja NPL kredita usled diferencijacije u definiciji i obuhvatu NPL kredita, kao i činjenica da je moguće izbegavanje prijavljivanja NPL kredita u punom iznosu, stvaraju značajne poteškoće u njihovom obuhvatu kao i sagledavanju uticaja NPL kredita na stabilnost finansijskog sektora u celini. NPL kreditima je posvećeno centralno mesto $u$ ovom radu. Imajući u vidu da se definicija NPL kredita značajno razlikuje između zemalja, potrebno je biti vrlo oprezan prilikom poređenja njihovog nivoa (Beck, Jakubik, \& Piloiu, 2013).

\section{NENAPLATIVA POTRAŽIVANJA - POJAM I TRETMAN}

Nenaplativa potraživanja se mogu definisati na različite načine. Uži pojam nenaplativih potraživanja tj. problematičnih kredita se odnosi na one kredite, koji ne donose prihod i kod kojih je nemoguće očekivati punu otplatu glavnice i kamate u budućnosti; kredite kod kojih je otplata glavnice ili kamate u kašnjenju od 90 i više dana ili krediti kod kojih je datum dospeća protekao, a naplata nije izvršena u potpunosti. Prema definiciji MMF-a (IMF, 2005), NPL kredit je kredit kod kojeg:

- dužnik kasni u otplati glavnice ili kamate 90 i više dana;

- je kamata za docnju dužu od 90 dana refinansirana, kapitalizovana ili je odloženo njeno plaćanje;

- dužnik kasni manje od 90 dana, ali je banka procenila da je sposobnost dužnika da otplati 
dug pogoršana i da je otplata duga dovedena u pitanje.

Kako ne postoji opšteprihvaćeni standard za definisanje problematičnih kredita, a supervizori na nacionalnom nivou primenjuju različite definicije za klasifikaciju kredita u kategoriju NPL kredita, zaključujemo da u praksi: većina država primenjuje granicu od 90 i više dana docnje kao kriterijum i prijavljuju celokupan iznos kredita $u$ kašnjenju kao NPL kredite.

Pojedine zemlje se svojim definicijama NPL kredita ne uklapaju u iznetu definiciju od strane MMF-a. Tako određene zemlje pod NPL kreditima podrazumevaju sve kredite koji su u docnji od $31 \mathrm{i}$ više dana ili 61 i više dana. Broj dana docnje po kreditu nije jedini kriterijum po kome se razlikuju definicije NPL kredita između zemalja. Od ostalih elemenata treba izdvojiti na primer Rumuniju, koja za klasifikaciju kredita uzima kriterijum finansijske sposobnosti dužnika i činjenicu da li je otpočet proces sudskog izvršenja. Takođe, bitan element definicije NPL kredita jeste da li se izražavaju u bruto izrazu, što jeste međunarodno prihvaćeni standard ili se je reč o neto iznosu. Posebno pitanje je kako klasifikovati višestruke kredite koje ima isti klijent. $U$ pojedinim zemljama, ukoliko je jedan kredit klasifikovan kao NPL kredit, onda se svi ostali krediti istog klijenta klasifikuju na istovetan način. Zanimljivo pitanje jeste pitanje tretmana i uloge kolaterala i garancija u procesu klasifikacije. Određena zakonodavstva ne razmatraju kolaterale i garancije za potrebe klasifikovanja kredita u redovan tj. NPL portfolio. (Barisitz, 2011).

Uobičajeno je da se bankarske krize povezuju sa visokim udelom NPL kredita u ukupnoj aktivi bankarskog sektora. Mnoge empirijske studije su se bavile analizom skupa mikro i makroekonomskih faktora, kao osnovnih pokretača bankarskih kriza, dok su obim i stopa rasta NPL kredita tj. ostalih varijabli koje opredeljuju kvalitet kreditnog portfolija u takvim statističkim modelima uzeti kao objašnjavajuća, egzogena varijabla. Glavni pokretač porasta NPL kredita kada su u pitanju makroekonomske varijable jeste rast GDP-a. Tesna povezanost između kreditnih performansi banaka i ekonomske aktivnosti predstavlja opšte poznatu tematiku. Međutim, treba naglasiti da ta povezanost nije ravnomerno iskazana u svim zemljama, pa su tako baltičke zemlje tokom perioda krize iskazale izuzetno visok nivo NPL kredita (npr. Letonija u 2009. - 18\%) u odnosu na realni GDP. Sa druge strane, pojedine zemlje su imale znatno manji iznos NPL kredita u kriznom periodu, kao što je npr. Nemačka. U Nemačkoj su NPL krediti povećani za manje od $1 \%$ iako je ekonomska aktivnost opala tokom 2009. godine za gotovo $5 \%$.

Pad opšte ekonomske aktivnosti jeste osnovni rizik za kvalitet aktive banke, ali nije dovoljno objašnjavajući faktor kretanja NPL kredita između zemalja i tokom vremena. Depresijacija deviznog kursa je na primer glavni pokretač porasta NPL kredita u onim zemljama koje se odlikuju visokim stepenom kredita odobrenih u stranoj valuti. Takođe, smanjenje cena akcija može imati negativan uticaj na kvalitet aktive banke naročito u zemljama sa izraženim tržištem akcija u odnosu na GDP. Pojedine empirijske analize su pokazale da porast aktivnih kamatnih stopa vodi ka porastu NPL kredita u budućnosti.

Nezavisno od toga koje makroekonomske varijable su analizirane kao uzročnici porasta NPL kredita, može se zaključiti da je analiza ovih varijabli od vitalnog značaja iz najmanje dva razloga:

1. sagledavanje glavnih pokretača porasta NPL kredita je ključno za utvrđivanje onih faktora koji sam finansijski sektor čine ranjivim. Kvalitet aktive i kreditni rizik u finansijskom sektoru predstavljaju bitan element makroprudencijalne kontrole.

2. redovno stres testiranje nad kreditnim portfolijom je zasnovano na makroekonomskim pretpostavkama u cilju kreiranja zajedničkih scenarija za sve finansijske institucije koje učestvuju u testiranju. Redovno sprovođenje stres testova je bitno i iz perspektive očuvanja poverenja u finansijski sistem.

Upravljanje problematičnim kreditima banaka može se sprovoditi u okviru same banke ili se mogu alocirati na druge institucije specijalizovane za obavljanje poslova restrukturiranja. Razlog da se upravljanje NPL kreditima i dalje vrši u okviru banke leži pre svega u činjenica da sama banka najbolje poznaje svoje dužnike i da će pokušati na različite načine da rehabilituje dužnike koji su prešli u NPL portfolio i eventualno in vrati $u$ 
regularni portfolio banke. Sa druge strane, potencijalni problem jeste činjenica da banke mogu biti manje objektivne prilikom donošenja odluke, što može rezultirati i povećanju postojećeg nivoa zaduženosti problematičnih klijenata. Ukoliko se banka odluči da za poslove upravljanje NPL kreditima angažuje specijalizovane institucije, to ne znači da se ceo NPL portfolio nužno mora poveriti specijalizovanim institucijama. Naprotiv, poželjno je da se deo NPL kredita zadrži u samoj banci, čije će službe kroz razvijene „work-out“ procedure, biti fokusirane na naplatu problematičnih potraživanja.

\section{3 ŠIRI ASPEKT ANALIZE NENAPLATIVIH POTRAŽIVANJA}

Hawkins \& Turner (1999) akcentuju uzroke koji dovode do kriza u bankarskom sistemu i u tom smislu ističu nekoliko kategorija koje utiču na kreiranje nestabilnosti bankarskog sistema:

1. mikroekonomski faktori - su vrlo bitni pored nedovoljno dobre regulative $u$ bankarskom sektoru, neadekvatne procene kreditnih rizika, neadekvatne ročne usklađenosti aktive i pasive. Prisustvo principal-agent problema je značajno, jer kreditni službenici motivisani ostvarenjem visokih bonusa zarad realizovanih kreditnih plasmana ne vode računa o rizičnosti samih kredita, što povećava izloženost banke riziku.

2. makroekonomski faktori-pogotovo dolaze do izražava dok zemalja u razvoju jer su one suočena sa znatno većom volatilnošću u makroekonomskoj sferi od razvijenih zemalja. U svakom slučaju, neophodno je da bankarski sistem bude spreman na ciklična privredna kretanja, depresijaciju deviznog kursa, pad cena aktive i slične pojave. I pored svih preduzetih mera, moguće je da neki dodatni iznenadni šokovi utiču na nespremnost bankarskih sistema da na adekvatan način reaguju u datom momentu kada makroekonomska kretanja imaju globalan uticaj.

3. sistemska rešenja - imajući u vidu da bankarski sistem ne funkcioniše izolovano od ukupnog privrednog sistema. Stabilnost bankarskog sistema može biti ugrožena neefikasnim poslovanjem velikih banaka $u$ državnom vlasništvu, banaka kod kojih je država najveći pojedinačni (ali ne i većinski) akcionar, kao i neadekvatnom pravnom regulativom i supervizorskim režimom nad bankarskim sistemom.

Pored gore navedenih faktora koji dovode do bankarskih kriza, ne treba zanemariti ni moral hazard, naročito ukoliko u slučaju nastupanja bankarskih kriza akcije Vlada pojedinih zemalja utiču da se neracionalno i neodgovorno ponašanje ohrabri u budućnosti. Ključno je da lica odgovorna za preuzimanje prevelikog rizika ne smeju ostati „nekažnjena“ tako da postojeći akcionari banaka moraju podneti gubitak do kojeg je i došlo usled neodgovornog rukovođenja bankom i neadekvatnog upravljanja rizicima. Istovremeno je neophodno održati poverenje u bankarski sistem što je u periodu krize vrlo izazovan posao. Neophodno je adekvatna zaštita interesa deponenata kroz razrađene šeme zaštite depozita i podršku centralnih banaka u cilju očuvanja stabilnosti bankarskog sistema. Za stabilnost bankarskog sistema i buduće funkcionisanje banaka od presudnog značaja je efikasno sprovođenje programa restrukturiranja.

lako se opšti nivo NPL kredita značajno razlikuje među pojedinim zemljama Centralne i Istočne Evrope, pojedine zakonitosti porasta NPL kredita su zajedničke. Pre svega to se odnosi na „pregrejanu“ kreditnu aktivnost u prethodnom periodu, pad BDP-a, neadekvatna struktura odobrenih kredita, porast nezaposlenosti, pad cena nekretnina i drugi makro- i mikroekonomski faktori. Globalnu sliku ambijenta u kojem se kreiraju uslovi za porast NPL kredita čine i jedinstveni faktori opadanja kreditne aktivnosti kao što su: problemi sa likvidnošću u bankarskom sistemu, emitovanje državnih obveznica, visok udeo zaduženosti izražen u stranim valutama itd.

Period ekspanzije kreditne aktivnosti u zemljama Centralne i Istočne Evrope je ostavio u nasleđe značajan iznos NPL kredita, koji je dodatno ugrozio funkcionisanje država već dovoljno poljuljanih posledicama globalne finansijske krize. Problematični krediti su značajna prepreka daljem ekonomskom razvoju, pošto imaju direktan uticaj na kreditni rast. Dolazi do obuzdavanja kreditne aktivnosti u pomenutim državama, a hitnost rešavanja pitanja NPL kredita postaje dominantna tema u zemljama Centralne i Istočne Evrope. Problematični krediti su najviše nivoe dostigli u onim privredama koje su doživele duboku 
ekonomsku krizu i u kojima je pre nastupanja same krize, kreditna ekspanzija bila najviše izražena. Tako su u Letoniji, Litvaniji i Crnoj Gori NPL pokazatelji dostigli $20 \%$, dok su države poput
Poljske i Turske ostvarile umerene vrednosti NPL indikatora (ove zemlje su izbegle recesiju i brzo su prevazišle krizni period) od $8,8 \%$ i $5,7 \%$, respektivno.

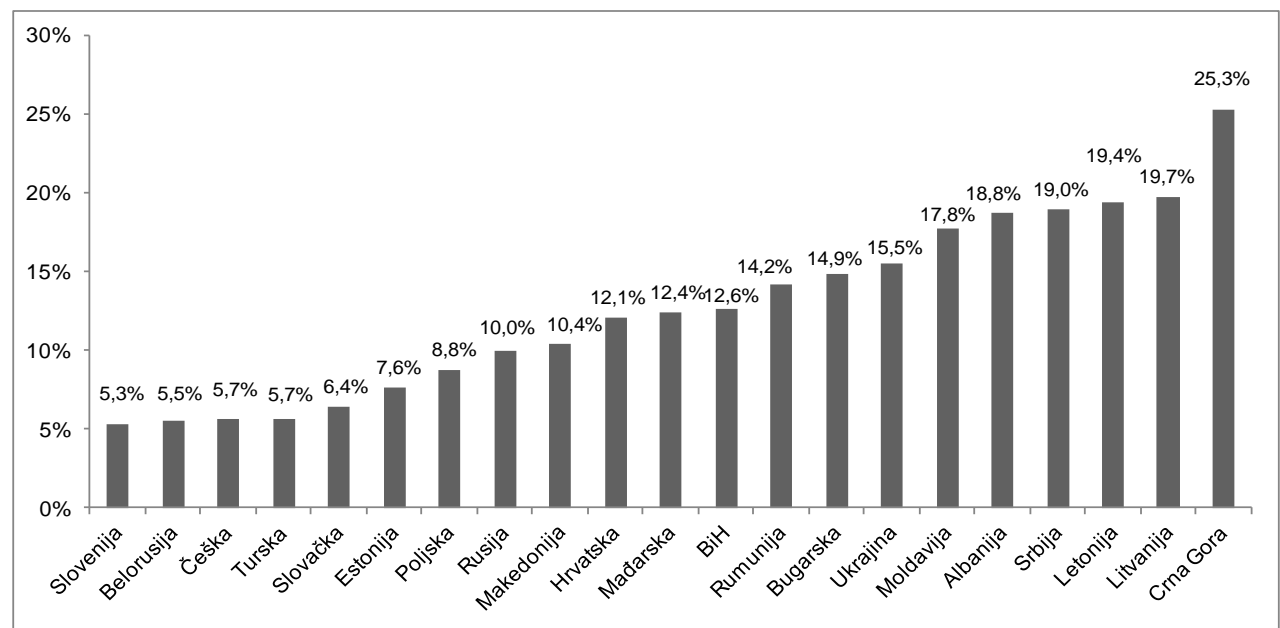

Slika 1: NPL krediti u zemljama Centralne i Istočne Evrope u periodu 2009. - 2011.

Izvor: (European Banking Coordination "Viena" Initiative, 2012, p. 12)

Jasno je da su visoki iznosi NPL kredita zaostavština prethodnog (kriznog) perioda, ali isto tako je jasno da sam ekonomski rast privreda neće biti dovoljan za potpuno rešavanje pitanja NPL kredita. Delimičan privredni oporavak u drugoj polovini 2009. godine, koji je doveo do usporenog rasta NPL pokazatelja i boljih performansi svetskih privreda, nije u potpunosti otklonio „oblak neizvesnosti“, jer su budući ekonomski izgledi u velikoj meri pod uticajem krize evrozone. Isto tako, nedvosmisleno se može zaključiti visok stepen povezanosti između makroekonomske stabilnosti u državi i ekspanzije NPL kredita. Vrlo interesantan $\mathrm{i}$ indikativan primer jeste italijanska privreda kao i NPL krediti u bankarskom sektoru Italije.

Kompanija Deloitte je u okviru svoje analize "The Deloitte Italian NPL Survey - Outlook for 20122013" utvrdila da privreda i nezaposlenost imaju dominantan uticaj na razvoj NPL kredita u italijanskom bankarskom sektoru (Deloitte, 2012). Istraživanje je sprovedeno tokom poslednjeg kvartala 2011. godine, a ključni makroekonomski pokazatelji nisu ukazivali na dobre performanse italijanske privrede:

- pad industrijske proizvodnje,

- najviši nivo nezaposlenosti dostignut u poslednjih 12 godina,

- pad opšte ekonomske aktivnosti meren BDP u prvom kvartalu 2012. godine, kao i
- izuzetno nizak nivo poverenja predstavljali su glavna obeležja italijanske ekonomije u posmatranom periodu.

U aprilu 2012. godine prema podacima Udruženja banaka Italije (Deloitte, 2012), NPL krediti su dostigli nivo od 108 milijardi evra (što je $6 \%$ od ukupnih plasmana privatnom sektoru), najviše još od 2000. godine. U 2011. je ostvaren rast BDP-a od $0,5 \%$, ali su predviđanja za 2012. bila negativna (pad od 1,9\%), uz očekivanu stagnaciju u 2013. godini. U martu 2012. godine, nezaposlenost je dostigla $9,8 \%$ uz veoma nepovoljnu strukturu nezaposlenih, jer je čak $36 \%$ nezaposlenih lica iznad 25 godina života.

Javni dug Italije, takođe, predstavlja krupan problem, jer je od svih država EU, samo Nemačka zemlja sa višim iznosom javnog duga u apsolutnom izrazu posmatrano, dok je jedino Grčka iznad Italije ukoliko se posmatra udeo javnog duga u BDP-u. Evidentni problemi u makroekonomskoj sferi su svoj efekat imali $u$ strukturnim problemima u bankarskom sektoru, koji su došli do izražaja u neprihvatljivo visokom iznosu problematičnih kredita na dugi rok posmatrano. Sprovedeno istraživanje kompanije Deloitte je pokazalo da (Deloitte, 2012):

- $70 \%$ ispitanika očekuje da će NPL krediti u budućem periodu nastaviti trend rasta, što se 
kasnije pokazalo tačnim na bazi rezultata iz aprila 2012. godine;

- NPL krediti u korporativnom sektoru rastu znatno brže nego što je to slučaj sa sektorom stanovništva;

- glavni razlog rasta problematičnih kredita, prema ispitanicima, jeste nezaposlenost (41\%), dok $28 \%$ smatra da je globalna finansijska kriza najviše doprinela intenzivnom rastu NPL kredita;

- najveći izazov u budućem periodu jeste oporavak privredne aktivnosti i povećanje ponude kredita;

- $\quad 77 \%$ banaka pitanje NPL kredita rešava kroz razvoj sopstvenih „work out" timova, jer je realno očekivati zbog prirode posla i tendencija u budućnosti, da će pomenuti timovi zahtevati angažovanje novih specijalista kao i značajnu podršku od strane menadžmenta banaka;

- 2/3 ispitanika smatra da se banke odlučuju na prodaju problematičnih kredita zarad smanjenja troškova upravljanja i poboljšanja kapitalne baze i likvidnosti (usled smanjenja prosečno ponderisane rizične aktive).

Svaki NPL kredit se može tretirati kao „ogledalo“ stabilnosti i efikasnosti funkcionisanja realnog sektora. Drugim rečima, realni sektor privrede sa velikim brojem preduzeća u problemima ima svoju refleksiju i u finansijskom sektoru kroz problematične kredite. Održavanje NPL kredita na postojećem nivou i odlaganje preduzimanja mera za njihovo rešavanje znači samo neproduktivno vezivanje sredstava u neprofitabilnim sektorima, onemogućavanje daljeg ekonomskog rasta i niži stepen ekonomske efikasnosti.

U uslovima visokog udela NPL kredita, banke više teže sprovođenju interne konsolidacije kako bi se poboljšao kvalitet aktive nego što se opredeljuju za distribuciju novih kredita. Posledično, visok iznos NPL kredita zahteva povećanje bančinih rezervisanja za potencijalne gubitke u budućnosti, što direktno umanjuje finansijski rezultat banke i smanjuje raspoloživa sredstva za nove kredite. Smanjena mogućnost kreditiranja utiče na slabljenje korporativnog sektora i ugrožava funkcionisanje preduzeća i privrede u celini. Banke su sve manje spremne da odobravaju kredite preduzećima, dok je proizvodni sektor uz nedovoljnu kapitalnu bazu dodatno oslabljen, što dovodi do pada agregatne tražnje. Pogoršani uslovi poslovanja se direktno odražavaju na korisnike kredita tj. dužnike, čija kreditna sposobnost nezadrživo opada i kreira se sve veći broj problematičnih kredita. Ulazi se u tzv. „začarani krug“ u kojem kao krajnje pesimistička rezultanta dolazi ne samo do sloma finansijskog i bankarskog sistema nego čak i bankrota države.

Tesna povezanost između finansijskog i realnog sektora sadržana u kategoriji NPL kredita može se sagledati i na primeru bankarskog sektora Srbije (Mirković, 2013). U dužem vremenskom periodu, ne mali broj ekonomista, upozorava da se Srbija ne nalazi samo u ozbiljnoj ekonomskoj, već i u sveopštoj društvenoj krizi: krizi koja gotovo da ne mimoilazi nijedan segment života, ali i krizi za koju do sada Srbija kao država nije pronašla adekvatno rešenje.

\section{STANJE NENAPLATIVIH POTRAŽIVANJA U BANKARSKOM SEKTORU SRBIJE}

Izrazito visok nivo nenaplativih potraživanja je neodrživ na dugi rok, pa je na centralnim bankama da učine dodatni napor na iznalaženju rešenja za NPL kredite. Ovi krediti „zarobljavaju“ kapital banke raspoloživ za dalje kreditiranje. Urušavanje kapitala banaka otežava prilagođavanje bankarskog sektora zahtevima bazelske regulative. Proces privrednog oporavka podrazumeva "čišćenje“ bilansa u finansijskom sistemu, uz istovremeno umanjivanje iznosa NPL kredita. Banke čine napor da obezbede maksimalan povraćaj svojih sredstava, bez daljeg generisanja gubitaka u svojim bilansima, pa se primenjuju različiti pristupi u odnosima sa dužnicima. Tako se često primenjuje fleksibilan pristup onim dužnicima koji pokažu visok nivo kooperativnosti u procesu otplate kredita, a pojedine države poput npr. Letonije, Rumunije, Moldavije, Poljske, Estonije i Srbije, su pokušale da potencijalno rešenje odnosa sa klijentima u kašnjenju pronađu u ohrabrivanju vansudskih restrukturiranja.

U 2012. godini, Srbija je ostvarila negativnu stopu rasta BDP-a (pad iznosi 1,5\%), što je prvi put nakon 2009. godine da je stopa rasta BDP-a bila negativna. Slabe performanse su ostvarene $u$ 2012. godini i u oblasti poljoprivrede (pad preko $20 \%$ ) usled sušne godine, kao i u industrijskoj 
proizvodnji - smanjenje za $2,9 \%$ u odnosu na 2011. godinu. U 2013. godini dolazi do delimičnog oporavka privrede, jer je izvozna aktivnost bila izražena pre svega zahvaljujući automobilskoj industriji (FIAT). Prema procenama Republičkog zavoda za statistiku, porast BDP-a ne godišnjem nivou je 2,4\% zahvaljujući boljim performansama poljoprivrede i manjem padu građevinske aktivnosti od prvobitno očekivane (Narodna banka Srbije, 2014). Nezaposlenost je i dalje jedan od najvećih problema srpske privrede, tako da je prema Anketi o zaposlenoj radnoj snazi Republičkog zavoda za statistiku, sprovedenoj u oktobru 2013. stopa nezaposlenosti i dalje vrlo visokih $20,1 \%$. Javni dug Republike Srbije, iznosi $63,6 \%$ BDP-a, što je znatno iznad regulatornih $45 \%$ prema Zakonu o budžetskom sistemu (http://www.nbs.rs/internet/cirilica/80/index.html).
Iznad prosečne performanse bankarskog sektora $\mathrm{u}$ pojedinima aspektima (npr. pokazatelj likvidnosti, adekvatnost kapitala) mogu da navedu na pogrešan zaključak o idiličnoj slici finansijskog sistema Srbije (Mirković, 2012). Situacija nije idilična, naprotiv poprima razmere zabrinjavajućeg karaktera ako se ima u vidu stanje NPL kredita. Naime, NPL krediti imaju tendenciju povećanja u dužem vremenskom periodu, tako da su na kraju trećeg kvartala 2013. godine iznosili 401,6 milijardi dinara, što je činilo $21.1 \%$ ukupno odobrenih (bruto) kredita (Narodna banka Srbije, 2013). Svaki peti plasman od ukupno odobrenih je imao tretman problematičnog plasmana na kraju trećeg tromesečja, što nije dobar pokazatelj „zdravlja“ bankarskog sektora Srbije niti indikator kvaliteta kreditnih portfelja banaka.

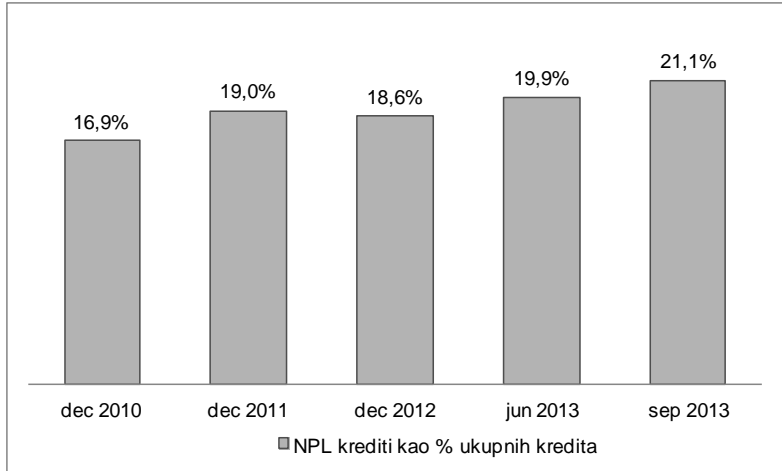

Slika 2a: NPL krediti kao \% ukupnih kredita

Izvor: NBS - Bankarski sektor u Srbiji - Izveštaj za III tromesečje 2013. godine

Slike (2a) i (2b) jasno pokazuju da su se problematični krediti kontinuirano povećavali dodatno podižući nivo zabrinutosti u celokupnom finansijskom sistemu. Treba napomenuti da je podrivanje stabilnosti bankarskog sistema dobrim delom i posledica kolapsa četiri banke na srpskom tržištu: 3 državne banke (Nove Agrobanke, Razvojne banke Vojvodine i Privredne banke Beograd) kao i jedne privatne banke (Univerzal banke). Uzroci kolapsa pomenutih banaka su višestruki ali se mogu sažeti u nekoliko glavnih stavki: potkapitalizovanost, nedovoljno i neefikasno upravljanje rizicima u bankama, kao i snažno prisustvo moralnog hazarda i nepostojanje volje da se problem reši. Dakle, na ukupnu sliku bankarskog sektora u vidu visokog procenta NPL kredita, treba dodati $\mathrm{i}$ inherentnu nestabilnost $\mathrm{i}$

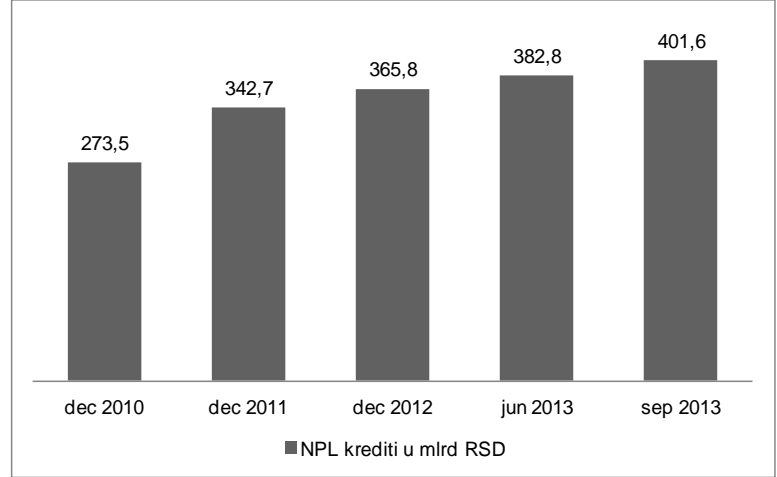

Slika 2b: NPL krediti u milijardama dinara

Izvor: NBS - Bankarski sektor u Srbiji - Izveštaj za III tromesečje 2013. godine

gašenje pojedinih, uglavnom državnih banaka, kao i nejasnu ili nedovoljno jasnu strategiju rešavanje situacije $u$ drugim problematičnim državnim bankama, čiji je opstanak vrlo neizvestan.

Narodna banka Srbije, kao glavni regulator poslovanja u bankarskom sistemu Srbije, je krajem 2012. godine donela nekoliko izmena koje su usmerene ka smanjenju nivoa problematičnih kredita (Narodna banka Srbije, 2012). Ključne izmene se mogu sažeti u nekoliko podgrupa i to:

- potraživanje je moguće ustupiti i licima koja nemaju sedište u Srbiji, licima koja se ne bave pretežno finansijskom delatnošću i povezanim licima sa bankom; 
- omogućeno je da banke vrše dodatno restrukturiranje potraživanja od preduzeća koja imaju izgleda za oporavak;

- ako je dužnik u docnji više od 720 dana, dozvoljeno je priznavanje hipoteke kao sredstva obezbeđenja po kreditu;

- dozvoljeno je bankama da prema sopstvenim internim procedurama utvrđuju kreditnu sposobnost klijenata, uvažavajući osobenosti svakog pojedinačnog dužnika.

Predviđeno je da se navedenim izmenama i dopunama Odluke o upravljanju rizicima i Odluke o klasifikaciji bilansne aktive i vanbilansnih stavki banke, bilansi banaka rasterete i stvore preduslovi za porast kreditne aktivnosti. To bi sa svoje strane značilo i da banke manje izdvajaju na ime rezervisanja za pokriće problematičnih plasmana $i$ podižu kvalitet svog kreditnog portfolija. Međutim, u praksi samo nekoliko banaka je iskoristilo pruženu mogućnost da svoj portfolio "očiste“ tako što će ustupiti nenaplativa potraživanja drugim pravnim licima. Prema podacima NBS, do kraja septembra, ukupno je 21,2 milijardi dinara nenaplativih potraživanja preneto iz bilansa banaka drugim licima.

Ne umanjujući značaj pada privredne aktivnosti i njen uticaj na porast NPL kredita, mora se istaći i da dobar deo "zasluga“ za njihovo kreiranje snose i same banke i njihov menadžment. Drugim rečima, banke su svojim pokušajima spašavanja velikih i važnih klijenata, prouzrokovale pad kvaliteta kreditnih portfelja. Reprogrami i restrukturiranje obaveza značajnih klijenata za banku su na kratak rok rešili problem, ali pre svega problem likvidnosti pomenutih klijenata. Bazični problem usled kojeg su pomenuti klijenti i došli u tešku situaciju nije rešen: privredna aktivnost nije oživljena, a ekonomske prilike u državi ne da nisu doprinosile njihovom oživljavanju nego su samo produbile krizu. Kreiran je mehanizam u kojem banke nisu u mogućnosti da naplate svoja potraživanja od klijenata, a sami klijenti su suočeni sa krizom likvidnosti i problemima izmirenja obaveza prema poveriocima, tako da je manevarski prostor svim akterima u finansijskom sektoru znatno sužen. Posledice takvog ambijenta su dalekosežne, kako za same učesnike u finansijskom sektoru, tako i po celokupnu ekonomsku situaciju u državi.

\section{NENAPLATIVA POTRAŽIVANJA - REŠAVANJE PROBLEMA}

Za stabilnost finansijskog sistema i pre svega bankarskog sistema od ključnog značaja jeste rešavanje pitanja NPL kredita. Sam sistem razrešavanja nenaplativih potraživanja kredita je praćeo nizom nedostataka u pravnom, regulatornom i poreskom smislu. Neefikasan pravni institucionalni okvir, predugo trajanje prinudne naplate kolaterala i otežano odvijanje sudskih procesa predstavljaju trajnu prepreku efikasnom rešavanju pitanja NPL kredita. Vansudsko restrukturiranje, iako brz i efikasan mehanizam, nije dovoljno iskorišćeno, a države Centralne i Istočne Evrope ne poseduju okvir za razrešavanje problema nesolventnosti fizičkih lica. U regulatornom smislu, problemi sa NPL kreditima se mogu ispoljiti kroz nedovoljnu superviziju poslovnih banaka, tako da neadekvatno klasifikovanje bilansne aktive i vanbilansnih stavki dovodi do toga da se gubici identifikuju prekasno sa aspekta efikasnog rešavanja samih kredita. Pojedina zakonodavstva ne podržavaju posedovanje nekretnina u portfoliju banaka ili poslovanje preko lica koja se bave nekretninama, što samo dodatno usložnjava proces uzimanja kolaterala i rešavanja NPL kredita kroz npr. svop transakcije tzv. „debt-to-equity swap“. Debt-toequity swap je refinansirajući sporazum koji karakteriše zamena duga za vlasnički udeo tj. zajmodavac dobija poziciju u vlasničkoj strukturi dužnika u zamenu za oprost duga. Svop transakcija se sprovodi da bi preduzeće koje je u problemima opstalo i nastavilo svoje funkcionisanje.

Genezom događaja koji su prethodili isticanju NPL kredita u prvi plan dolazimo do zaključka da su godine kreditne ekspanzije u zemljama u razvoju, a nakon globalne ekonomske krize, bile pokretač negativnih kretanja. Tada je struktura ukupnih kredita bila uglavnom u korist potrošačkih i stambenih kredita, dok pre same kreditne ekspanzije ove kategorije kredita nisu bile značajano zastupljene u strukturi kredita. Nastupanjem krize i porastom iznosa NPL kredita sa pomenutom strukturom stvorilo je problem $u$ onim bankarskim sistemima koji nisu imali dovoljno iskustva sa tretmanom ovih kategorija kredita. U nešto povoljnijoj poziciji su bile afilijacije stranih banaka u zemljama u razvoju koje su se 
mogle osloniti na iskustvo svojih matičnih banaka u rešavanju problema NPL kredita.

U cilju prepoznavanja NPL kredita u ranoj fazi, banke su posebnu pažnju posvetile efikasnom upravljanju rizicima i izmenama internih politika i procedura. Bliska saradnja između menadžmenta banke i sektora za upravljanje rizicima je neophodno da bi se održao kvalitet kreditnog portfolija. Direktna odgovornosti menadžmenta banke u oblasti formiranja specijalizovane „work out" službe koja se bavi NPL kreditima je izuzetno značajna sa aspekta efikasnog funkcionisanja same banke. lako je u interesu banke da gotovo po svaku cenu izvrše „čišćenje“ svog bilansa stanja, to ne znači da procesu rešavanja NPL kredita treba prići naprečac i nedovoljno obazrivo, bez detaljne i temeljne analize i kadrovski kvalitetnog formiranja „work out" službe. Banke često primenjuju tzv. „prijateljski“ pristup rešavanju NPL kredita u nastojanju da bar delom naplate svoje potraživanje. Istovremeno, banke su svesne da agresivniji nastup prema klijentima može doneti negativan reputacioni rizik, što dodatno podiže nivo opreznosti pri izboru metoda i načinu ophođenja sa klijentima u docnji.

Povezanost između banke i klijenata koji kasne u otplati kredita je bitna čak i od momenta kada se klijent kasni sa otplatom prve rate kredita, jer se u ranoj fazi može izvršiti restrukturiranje kredita sa neznatnim izmenama $u$ amortizacionom planu, a sam kredit se ne mora klasifikovati kao problematičan kredit, već ostati deo regularnog portfolija banke. Suština najvećeg broja primenjenih solucija za razrešavanje problematike NPL kredita je sadržana u normalizovanju otplate kredita od strane klijenta (European Banking Coordination "Vienna" Initiative, 2012). Prilikom naplate kredita odobrenih stanovništvu, banke se oslanjaju na "meke“ metode naplate potraživanja (korišćenjem kol-centara, SMS poruka itd.) i fokus je na povraćaju preostalog iznosa duga, dok je u slučaju korporativnih kredita akcenat na restrukturiranju. Svrha restrukturiranja je izbegavanje pesimističkog scenarija za preduzeća-dužnike: bankrota ili likvidacije. Nastoji se održati aktivnim tekući račun i omogućiti nastavak poslovanja preduzeća, iako u pojedinim situacijama to zahteva i snižavanje kamatnih stopa ili produžetak perioda otplate kredita.
Optimalno rešenje NPL kredita ne postoji, ali se uglavnom primenjuju rešenja koja se razlikuju prema stepenu centralizacije I prema načinu finansiranja (privatna ili javna inicijativa ili partnerstvo). Kod centralizovanog pristupa rešavanja NPL kredita prednosti su "čišćenje“ bilansa banaka, fokus banaka na svoje ključne funkcije, centralizovano vlasništvo nad kolateralom, definisanje specifičnih uslova za kupovinu NPL kredita itd. Nedostaci centralizovanog pristupa dolaze do izražaja u neefikasnom upravljanju ili bar manje efikasnom upravljanju nego u privatnim kompanijama, većim troškovima i većoj izloženosti političkim pritiscima. Kod centralizovanog pristupa podrazumeva se da država ima aktivnu ulogu u procesu „čišćenja“ bilansa banke, restrukturiranju kredita i obezbeđivanju fiskalne podrške. U principu se decentralizovani pristup rešavanja NPL kredita primenjuje ukoliko je postojeći stok NPL kredita neznatan pa je logično da banke, koje sama najbolje poznaju svoje dužnike, u direktnom kontaktu sa dužnicima pokušaju pronaći optimalno rešenje. Najizraženija prednost rešavanja pitanja NPL kredita putem formiranja specijalizovane „work out" službe u okviru banke jeste dobro poznavanje pojedinačnog dužnika i specifičan pristup svakom od njih. Mana ovog načina rešavanja pitanja NPL kredita jeste gubitak fokusa sa osnovnih funkcija banke, bilans banke se ne „čisti“ a vrlo često zemlje u razvoju ne raspolažu dovoljno dobro obučenim i osposobljenim kadrovima za realizaciju vrlo zahtevnih zadataka, jer su ove zemlje po prvi put suočene sa problemom nenaplativih potraživanja. Sa druge strane, formiranje privatne kompanije koja će upravljati NPL kreditima, glavni nedostatak ima u nedovoljnom dobrom poznavanju samog dužnika, ali prednosti ovog oblika rešavanja pitanja NPL kredita su: akcenat na restrukturiranju, „čiscćenje“ bilansa banke, posedovanje specijalizovanih znanja i veština neophodnih za efikasno sprovođenje procesa, gotovo potpuno eliminisan politički pritisak i izbegavanje dodatnih troškova (Dragutinović \& Živkovic, 2014).

\section{ZAKLJUČAK}

U epicentar pažnje ekonomista NPL krediti su došli sa ubrzanjem globalne ekonomske krize i produžavanjem krize evrozone, iako kao 
kategorija NPL krediti nisu novijeg datuma. Međuzavisnost i povezanost krize $u$ realnom i finansijskom sektoru, nužno nameće potrebu o adekvatnom praćenju i rešavanju pitanja NPL kredita u bankarskom sektoru. Restrukturiranje bankarskih sistema se sprovodi na različite načine, pri čemu ne postoje uniformne mere koje se primenjuju u datoj situaciji, već se mere značajno razlikuju od jedne do druge zemlje. Ipak, pojedine zajedničke karakteristike primenjenih mera mogu poslužiti kao osnova i dobro iskustvo pre svega za zemlje u razvoju, koje do sada nisu imale dovoljno dodira sa problemima restrukturiranja i tretmanom NPL kredita.

Vrlo bitnu, gotovo presudnu ulogu, u kontekstu rešavanja pitanja NPL kredita $i$ obezbeđivanju stabilnosti bankarskog sistema imaju centralne banke. Centralne banke moraju pokazati spremnost da reše problem nesolventnih banaka na način koji će obezbediti stabilnost finansijskog sistema na dugi rok. Preduzimanje preventivnih mera i akcija („ex ante") je nužno i jeftinije rešenje, umesto da se „ex post" deluje nakon što obim NPL kredita dostigne visok i na dugi rok neodrživ nivo. Proces očuvanja bankarskog sistema ne znači da se po svaku cenu mora zadržati postojeća struktura akcionara ili menadžera, jer je moral hazard izuzetno izražen. Unapređenja u supervizorskim procedurama su neophodna kako bi se preventivno delovalo na probleme koji nastaju usled rasta NPL kredita. Visoko obučeni supervizori sa specijalizovanim znanjima i nezavisni od političkog establišmenta su odgovorni za efikasno restrukturiranje bankarskog sistema.

Kritična stvar u pronalaženju rešenja za problematične kredite u portfelju banaka jeste vremenski momenat. Naime, nije dovoljno samo uočiti da postoje problemi u izmirenju obaveza od strane dužnika, već je potrebno sve učiniti da se situacija ne pogorša dodatno u budućnosti, a to je moguće samo revidiranjem postojećih procedura i politika upravljanja rizicima banke. Aktivnosti razrešavanja problema NPL kredita se mogu obavljati u okviru banke formiranjem specijalizovanih „work out" službi ili poveravanjem ovih poslova specijalizovanih agencijama izvan banke. Zemlje u razvoju uglavnom se opredeljuju za prvu varijantu tako što se kroz formiranje „work out" službi ostvaruje tesna saradnja sa klijentima - dužnicima, kako bi se iznašlo optimalno obostrano rešenje u datim okolnostima. Naravno, banke se opredeljuju za jedan od dva moguća rešenja imajući u vidu nivo razvijenosti finansijskog tržišta posmatrane zemlje i dostignuti nivo ukupnih NPL kredita. Krajnji cilj, nezavisno od izabrane varijante, jeste „čišćenje“ bilansa banaka i oslobađanje kapitala, koji je blokiran u NPL kreditima.

Za razliku od razvijenih zemalja koje imaju više iskustva u tretmanu NPL kredita, zemlje u razvoju su u situaciji da koriste iskustva drugih zemalja uz dodatnu specifičnost, oličenu u tome da ove zemlje treba da apsorbuju znatno viši iznos rizika u odsustvu efikasnog tržišta. Posledično, banke treba da raspolažu adekvatnim kapitalom za pokriće preuzetog rizika, kao i odgovarajućim veštinama upravljanja i procene svih vrsta rizika sa kojima se banka suočava. U uslovima kada je kapital deficitarna kategorija, držanje nedovoljno iskorišćenog kapitala vezanog za problematične kredite je u najmanju ruku neproduktivno sa aspekta budućeg rasta bankarskog sektora. $U$ tom smislu, imperativ za sve finansijske institucije (u prvom redu banke) je oslobađanje od problematičnih kredita, čišćenje bilansa i produktivno angažovanje kapitala u cilju obavljanja osnovnih delatnosti i izlasku u susret regulatornim zahtevima.

\section{CITIRANI RADOVI}

Barisitz, S. (2011). Nonperforming Loans in CESEE - What Do They Comprise?. Focus on European Economic Integration, Q4/11, Österreichische Nationalbank, Vienna. Retrieved from: http://www.oenb.at/de/img/feei_2011_q4_studies_1_tcm14-241680.pdf

Beck, R., Jakubik, P. \& Piloiu A. (2013). Nonperforming Loans - what matters in addition to the economic cycle?. Working Paper Series No. 1515, February 2013.

Deloitte. (2012). The Deloitte Italian NPL survey - Outlook for 2012 - 2013. Retrieved from: http://www.deloitte.com/. 
Dragutinović, D., Živković, B. (2014). Problematični krediti u bankarstvu. Ekonomska politika u 2014: mogućnosti privrednog rasta u uslovima reformi i fiskalne konsolidacije. Ekonomski fakultet, Beograd, 2014., 165 - 186.

European Banking Coordination "Viena" Initiative. (2012, 03). Working Group on NPLs in Central, Eastern and Southeastern Europe. Retrieved from World Bank: http://siteresources.worldbank.org/EXTFINANCIALSECTOR/Resources/2828841242281415644/EBCI-NPL-WG-report.pdf

Hawkins, J., Turner, P. (1999).Bank restructuring in practice: an overview. Retrieved from: https://www.bis.org/publ/plcy06a.pdf

IMF (2005). The treatment of Nonperforming Loans. Preuzeto 24.02.2013. sa sajta: http://www.imf.org/external/pubs/ft/bop/2005/05-29.pdf

Mirković, V. (2012). Bankarski sektor Srbije: ostvarene performanse i izazovi u budućnosti, Ekonomski vidici, 4, 643. - 662.

Mirković, V. (2013). Privreda Srbije u 2013. godini: nagoveštaj postepenog izlaska iz krize ili produžetak negativnog trenda. Zbornik radova „Izazovi za ekonomsku politiku Srbije 2013. godine“, Beograd: Ekonomski fakultet, 183 - 194.

Narodna banka Srbije (2012). Stvoreni preduslovi za efikasnije rešavanje problematičnih kredita. Retrieved from: http://www.nbs.rs/internet/cirilica/scripts/showContent.html?id=6218\&konverzija=no

Narodna banka Srbije (2013). Bankarski sektor u Srbiji - Izveštaj za III tromesečje 2013. godine. Retrieved from: http://www.nbs.rs/internet/cirilica/55/55_4/index.html

Narodna banka Srbije (2014). Izveštaj o inflaciji - februar 2014. Retrieved from: http://www.nbs.rs/internet/cirilica/90/ioi.html\#statistika

Narodna banka Srbije (2014). Retrieved from: http://www.nbs.rs/internet/cirilica/80/index.html

Datum prve prijave:

Datum prijema korigovanog rada:

Datum prihvatanja članka:
25.01.2014.

13.06.2014.

23.06.2014.

\section{Kako citirati ovaj rad?}

Style - APA Sixth Edition

Mirković, V., \& Knežević, M. (2014, 07 15). Rešavanje problema nenaplativih potraživanja kao esencijalni faktor stabilnosti bankarskog sistema. (Z. Čekerevac, Ed.) FBIM Transactions, 2(2), 224-234. doi:10.12709/fbim.02.02.02.22

Style - Chicago Fifteenth Edition:

Mirković, Vladimir, and Marija Knežević. 2014. "Rešavanje problema nenaplativih potraživanja kao esencijalni faktor stabilnosti bankarskog sistema." Edited by Zoran Čekerevac. FBIM Transactions (MESTE) 2 (2): 224-234. doi:10.12709/fbim.02.02.02.22.

Style - GOST Name Sort:

Mirković Vladimir and Knežević Marija Rešavanje problema nenaplativih potraživanja kao esencijalni faktor stabilnosti bankarskog sistema [Journal] // FBIM Transactions / ed. Čekerevac Zoran. - Beograd : MESTE, 07 15, 2014. - 2 : Vol. 2. - pp. 224-234.

Style - Harvard Anglia:

Mirković, V. \& Knežević, M., 2014. Rešavanje problema nenaplativih potraživanja kao esencijalni faktor stabilnosti bankarskog sistema. FBIM Transactions, 15 07, 2(2), pp. 224-234.

Style - ISO 690 Numerical Reference:

Rešavanje problema nenaplativih potraživanja kao esencijalni faktor stabilnosti bankarskog sistema. Mirković, Vladimir and Knežević, Marija. [ed.] Zoran Čekerevac. 2, Beograd : MESTE, 07 15, 2014, FBIM Transactions, Vol. 2, pp. 224-234. 